\title{
PENGARUH GOOD CORPORATE GOVERNANCE TERHADAP PROFITABILITAS PERBANKAN DENGAN RISIKO KREDIT SEBAGAI VARIABEL INTERVENING (PADA PERBANKAN YANG TERDAFTAR DI BEI PERIODE 2014-2016)
}

\author{
Komang Hevy Aryani ${ }^{1}$ \\ ${ }^{1}$ Fakultas Ekonomi dan Bisnis Universitas Mataram, khevyaryani@gmail.com
}

\begin{abstract}
ABSTRAK
Penelitian ini bertujuan untuk mengetahui pengaruh Good Corporate Governance (GCG) terhadap profitabilitas perbankan melalui risiko kredit sebagai variabel intervening. Populasi dalam penelitian ini adalah perusahaan perbankan yang terdaftardi Bursa Efek Indonesia periode 2014-2016. Sampel dalam penelitian ini dipilih menggunakan metode purposive sampling sehingga diperoleh sampel perusahaan sebanyak 39 perusahaan. Metode analisis data dan pengujian hipotesis dalam penelitian ini menggunakan analisis jalur (path analysis) dengan model data panel. Hasil penelitian ini menunjukkan bahwa komisaris independen tidak berpengaruh terhadap profitabilitas tetapi berpengaruh terhadap risiko kredit dimana semakin tinggi proporsi komisaris independen semakin rendah risiko kredit, dewan direksi berpengaruh terhadap profitabilitas dan risiko kredit dimana semakin tinggi jumlah dewan direksi, maka semakin tinggi profitabilitas dan semakin rendah risiko kredit, kepemilikan manajerial tidak berpengaruh terhadap profitabilitas tetapi berpengaruh terhadap risiko kredit dimana semakin tinggi proporsi kepemilikan manajerial semakin rendah risiko kredit dan juga ditemukan risiko kredit berpengaruh terhadap profitabilitas dimana semakin tinggi risiko kredit, maka semakin rendah profitabilitas. Selain itu, penelitian ini juga menunjukan risiko kredit dapat menjadi Variabel Intervening untuk GCG.

Kata-kata Kunci : Komisaris independen, dewan direksi, kepemilikan manajerial, risiko kredit, profitabilitas
\end{abstract}

\begin{abstract}
This study aims to determinate the effect of Good Corporate Governance (GCG) on profitability in banking industry with credit risk as intervening variable. The Population in this study is banking industries which are listed in Indonesia Stock Exchange during 2014 to 2016. Sample on this examination is chosen using purposive sampling method, thus gotten 39 entities as sample. Data analysis method and hypotheses are examined using path analysis with panel data. The result show that independent board have no effect on profitability but have an effect on credit risk where the higher the proportion on independent board hence the lower credit risk, board of director has an effect on profitability and credit risk where higher board of director hence higher profitability and hence the lower credit risk, insider ownership have no effect on profitability but have an effect on credit risk where the higher insider ownership hence the lower credit risk and credit risk influence to profitability where higher credit risk hence lower profitability. In addition, this study also shows credit risk can be an interrvening variable for GCG.
\end{abstract}

Key Words: independent board, board of director, insider ownership, credit risk, profitability 


\section{Latar Belakang}

\section{PENDAHULUAN}

Dalam suatu sistem perekonomian, perbankan memegang sebuah peranan penting sebagai penunjang kemajuan ekonomi suatu negara. tanpa diskriminasi (Ibadil dan Haryanto, 2014). Menurut Ali (2006:2) terdapat dua peran utama bank yakni berkaitan dengan lembaga kepercayaan (agent of trust) dan sebagai agen pembangunan (agent of development) dalam perekonomian. Sebagai agen kepercayaan, dalam menjalankan perannya sebagai lembaga intermediasi bank dituntut untuk selalu mampu menunjukan dirinya dalam kondisi yang sehat, karena sedikit saja timbul keraguan masyarakat akan kondisi kesehatan sebuah perbankan akan berimbas pada hilangnya kepercayaan masyarakat pada bank lainnya sehingga menimbulkan efek domino.

Dewasa ini, kinerja bank terus menjadi sorotan publik terlebih dengan tingginya tingkat penurunan terhadap profitabilitas perbankan dari tahun 2014-2016 yang terlihat dari tingkat Return on Asset (ROA) perbankan pada tahun 2014 sebesar 2,85 persen mengalami penurunan yang cukup tinggi pada tahun 2015 menjadi 2,32 persen dan kembali mengalami penurunan pada tahun 2016 menjadi 2,23 persen walaupun tidak sebesar penurunan pada tahun 2015 (www.ojk.go.id).

Banyak kajian dan penelitian yang mengatakan bahwa tinggi rendahnya profitabilitas perbankan dipengaruhi oleh implementasi Good Corporate Governance. Kurangnya penerapan Good Corporate Governance (GCG) pada perbankan terlihat pada tahun 2013 masih ada empat bank yang melanggar asas Good Corporate Governance (GCG) sehingga diberikan sanksi pembatasan oleh Bank Indonesia (BI). Keempat bank tersebut adalah PT Bank Mega Tbk, PT Bank Panin Tbk, PT Bank Jabar Banten Tbk dan PT Bank Mestika Dharma (www.hukumonline.com.).

Good Corporate Governance (GCG) merupakan salah satu elemen kunci dalam meningkatkan efisiensi ekonomis, yang meliputi serangkaian hubungan antara manajemen perusahaan, dewan komisaris, pemegang saham dan stakeholders lainnya. Pelaksanaan Good Corporate Governance (GCG) sangat diperlukan untuk membangun kepercayaan masyarakat dan dunia internasional sebagai syarat mutlak bagi dunia perbankan untuk berkembang dengan baik dan sehat (OJK, 2016).

Kesadaran mengenai pentingnya penerapan GCG pada perbankan nasional terlihat dari dikeluarkannya Pedoman Penerapan Good Corporate Governance untuk Perbankan Indonesia oleh Komite Nasional Kebijakan Corporate Governance (KNKCG) tahun 2004 dan diberlakuannya Peraturan Otoritas Jasa Keuangan (POJK) No. 55/POJK.03/2016 tentang Penerapan Tata Kelola serta Surat Edaran Bank Indonesia (SEBI) No. 15/15/DPNP pada 29 April 2013 tentang pelaksanaan Good Corporate Governance bagi bank Umum.

Dalam penelitian ini GCG diproksikan oleh komisaris independen, dewan direksi, dan kepemilikan manajerial. Dipilihnya komisaris independen, dewan direksi, dan kepemilikan manajerial karena keberadaan ketiganya sangat menentukan terlaksananya pengimplementasian GCG dengan baik. Adanya koordinasi yang selaras antatra ketiganya berguna untuk menghindari benturan kepentingan (conflict of interest) di dalam pelaksanaan tugas seluruh tingkatan atau jenjang organisasi bank serta menghindari pelaksanaan manajemen yang tidak sehat.

Selain GCG, tinggi rendahnya profitabilitas perbankan juga dipengaruhi oleh berbagai risiko yang diderita perbankan khususnya risiko kredit. Risiko kredit merupakan salah satu risiko utama perbankan yang tidak mungkin dapat dihindari oleh setiap perbankan. Hal ini terlihat pada tabel 1.1 sebagai berikut: 
Tabel 1.1 Rata-rata rasio ROA dan NPL Perbankan Periode 2014-2016

\begin{tabular}{|l|c|c|c|}
\hline $\mathbf{( \% )}$ & $\mathbf{2 0 1 4}$ & $\mathbf{2 0 1 5}$ & $\mathbf{2 0 1 6}$ \\
\hline ROA & 2.85 & 2.32 & 2.23 \\
\hline NPL & 2.04 & 2.39 & 2.93 \\
\hline
\end{tabular}

Sumber: www.ojk.go.id.

Berdasarkan tabel 1.1, dapat diketahui bahwa terdapat kecenderungan bahwa Return On Asset (ROA) perbankan mengalami penurunan dari tahun 2014-2016, sedangkan Risiko Kredit atau Non Performing Loan (NPL) perbankan cenderung mengalami kenaikan dari tahun 2014-2016.

Risiko kredit adalah pinjaman bermasalah yaitu ketika pihak debitur tidak mampu memenuhi kewajibannya untuk membayar angsuran (cicilan) pokok kredit beserta bunga yang telah disepakati kedua belah pihak dalam perjanjian kredit. Dipilihnya risiko tersebut karena bagi kebanyakan bank risiko ini merupakan unsur risiko terbesar karena margin yang diterima bank dalam kegiataan leading relatif kecil. (Ali, 2006:25). Risiko kredit merupakan risiko yang sangat berpengaruh pada tingkat pendapatan suatu bank sehingga keberadaannya dianggap sangat menentukan tingkat kestabilan kondisi keuangan suatu perusahaan. risiko kredit dianggap penting karena risiko lainnya merupakan dampak dari risiko kredit (Ariestya dan Ardiana, 2017).

Terdapat keterkaitan antara GCG dan risiko kredit dimana rendahnya komitmen penerapan GCG berkaitan erat dengan tingkat risiko yang dihadapi perbankan, bank yang memiliki sistem informasi yang baik sekalipun dapat berpotensi mengalami kegagalan apabila prinsip-prinsip tata kelola tidak berjalan dengan baik. Saat risiko kredit yang dihadapi rendah atau setidaknya berada dalam batas wajar, mengindikasikan baiknya penerapan manajemen risiko yang juga dijadikan salah satu penilaian untuk melihat kualitas penerapan GCG perusahaan. Selain itu, GCG dan manajemen risiko juga menjadi faktor kunci keterpurukan industri perbankan dimasa krisis tahun 1997 (Akmal, 2008).

Pengimplementasian GCG akan lebih maksimal jika diikuti dengan penanganan risiko kredit yang baik yang akan berpengaruh pada tinggi rendahnya profitabilitas perbankan sehingga mampu menjaga dan meningkatkan kinerja bank. Hal ini ditegaskan oleh penelitian Andriani dan Rozak (2016) serta Puspitasari (2014) yang meneliti GCG terhadap risiko kredit dan menemukan bahwa GCG berpengaruh terhadap risiko kredit. Penelitian yang menggunakan risiko kredit sebagai variabel intervening juga telah dilakukan oleh beberapa peneliti seperti Setyorini (2015) dan Setyawati (2016) dan menemukan yang menemukan Risiko Kredit berpengaruh langsung terhadap Return on Asset (ROA). Selain itu, risiko kredit mampu berperan sebagai variabel intervening serta memperkuat hubungan antara GCG dengan Return on Asset (ROA).

\section{Rumusan Masalah}

Berdasarkan pada latar belakang masalah di atas, maka rumusan masalah dalam penelitian ini adalah: 1) Apakah Komisaris Independen berpengaruh terhadap Profitabilitas? 2) Apakah Dewan Direksi berpengaruh terhadap Profitabilitas? 3) Apakah Kepemilikan Manajerial berpengaruh terhadap Profitabilitas? 4) Apakah Komisaris Independen berpengaruh terhadap Risiko Kredit? 5) Apakah Dewan Direksi berpengaruh terhadap Risiko Kredit? 6) Apakah Kepemilikan Manajerial berpengaruh terhadap Risiko Kredit? 7) Apakah Risiko Kredit berpengaruh terhadap Profitabilitas? 8) Apakah Komisaris Independen berpengaruh terhadap Profitabilitas melalui Risiko Kredit? 9)Apakah Dewan Direksi berpengaruh terhadap Profitabilitas melalui Risiko 
Kredit? 10) Apakah Kepemilikan Manajerial berpengaruh terhadap Profitabilitas melalui Risiko Kredit?

\section{TINJAUAN LITERATUR}

Penelitian yang meneliti mengenai komisaris independen terhadap profitabilitas telah dilakukan oleh beberapa penelitian terdahulu seperti penelitian yang dilakukan oleh Widyati (2013) dan Riniati (2015) hasil penelitiannya menunjukkan proporsi komisaris independen berpengaruh positif terhadap ROA dikarenakan semakin besar jumlah komisaris independen maka semakin mudah untuk mengendalikan dan memonitor kegiatan perusahaan. Selain itu menurut Hasanah (2013) yang menemukan hasil yang serupa berpendapat bahwa dewan komisaris independen membantu merencankan strategi jangka panjang perusahaan dan secara berkala melakukan review atas implementasi strategi tersebut dan akan memberikan benefit yang tinggi bagi perusahaan.

Menurut penelitian yang dilakukan Halini (2012), Hasanah (2013), dan Aprianingsih (2016) menyimpulkan bahwa semakin tinggi keberadaan dewan direksi maka ROA perbankan semakin tinggi dan pengimplementasian GCG akan semakin baik, hal ini dikarenakan dewan direksi bertanggungjawab dan berwenang di dalam setiap kegiatan operasional perusahaan baik di dalam maupun di luar perusahaan.

Hasanah (2013) serta Indarti dan Extaliyus (2013) meneliti pengaruh kepemilikan manajerial terhadap ROA dan menemukan hubungan yang positif antara keduanya dimana dengan adanya kepemilikan manajerial akan mampu mengurangi konflik antara pemegang saham dan manajer sehingga keuntungan perusahaan semakin besar.

Menurut Jensen \& Meckling, 1976 dan Barnhart S. W.,1998 dalam Joeswanto dan Malelak (2015) semakin besar proporsi Komisaris Independen, maka semakin tinggi independensi dan efektivitas corporate board, sehingga Risiko Kredit dapat dijaga dan diminimalisir agar berada pada ambang batas yang maksimum sehingga manajemen risiko menjadi semakin efektif dan baik. Hal ini didukung oleh penelitian Setyorini (2015) dan Saefitrie (2017) yang menemukan komisaris independen berpengaruh negatif terhadap Risiko Kredit. Berdasarkan penelitian yang dilakukan Setyawati (2016) serta Ariestya dan Ardiana (2016) menyimpulkan dengan adanya pengimplementasian GCG yang baik akan mampu mengurangi dan meminimalisir risiko kredit yang akan dihadapi perbankan secara efektif.

Setyorini (2015) meneliti pengaruh kepemilikan manajerial terhadap kredit (NPL) dan menemukan hubungan negatif antara keduanya dimana semakin tinggi kepemilikan manajerial akan mengurangi risiko kredit yang dihadapi perbankan.

Eng (2013) dan Attar dkk (2014) yang meneliti pengaruh risiko kredit (NPL) bank internasional dan bank nasional yang terdaftar di Bursa Efek Indonesia dan menemukan NPL berpengaruh terhadap kinerja keuangan yang diukur dengan ROA dan dengan demikian perbankan disarankan agar selalu melakukan monitoring ketat atas kualitas kreditnya agar NPL-nya dapat tetap terkendali.

Berdasarkan penelitian Setyorini (2015) dan Setyawati (2016) yang menemukan bahwa impelementasi Good Corporate Governance (GCG) yang diproksikan dengan komisaris independen mampu meningkatkan Return On Asset (ROA) melalui risiko kredit (NPL). Dengan adanya Komisaris Independen sebagai salah satu mekanisme Good Corporate Governance (GCG), risiko kredit dapat dikelola dengan baik sehingga profitabilitas perusahaan pun akan semakin baik pula. Penelitian yang meneliti GCG terhadap profiibilitas dengan menggunakan risiko kredit sebagai 
variabel intervening telah dilakukan oleh beberapa penelitian namun rata-rata penelitan memproksikan GCG menggunakan nilai komposit GCG atau Corporate Governance Perseption Index (CGPI) dimana pengukuran GCG dilakukan secara keseluruhan seperti penelitian Permatasari dan Novitasary (2014) serta Ariestya dan Ardiana (2016) yang menyatakan risiko kredit mampu berperan sebagai variabel intervening dan mampu memperkuat hubungan antara GCG dan ROA. Sedangkan dalam penelitian ini menguji dewan direksi yang merupakan salah satu struktur GCG yang palingg penting keberadaannya. Setyorini (2015) meneliti pengaruh kepemilikan manajerial terhadap ROA melalui risiko kredit (NPL) dan menemukan bahwa risiko kredit mampu berperan sebagai variabel intervening secara murni (pure mediation)

\section{METODE PENELITIAN}

\section{Jenis Penelitian}

Jenis penelitian ini menurut karakteristik dan pendekatannya adalah penelitian kausal-asosiatif (ex-post facto) dimana menelitihubungan sebab akibat antara dua variabel atau lebih yaitu antara variabel indipenden (variabel yang mempengaruhi) dan variabel dependen (yang dipengaruhi) dan dilakukan untuk meneliti peristiwa yang telah terjadi dan kemudian meruntut kebelakang untuk mengetahui faktor-faktor yang menyebabkan timbulnya kejadian tersebut (Sugiyono,2011:36)

\section{Populasi dan Sampel Penelitian}

Populasi dalam penelitian ini adalah perusahaan perbankan yang terdaftar di BEI tahun 2014-2016 yang berjumlah 44 perusahaan. Teknik penarikan data dengan mengambil sampel penelitian menggunakan metode purposive sampling sehingga diperoleh sampel sebanyak 39 perusahaan. Periode waktu yang digunakan adalah selama 3 tahun yaitu periode waktu 2014, 2015, dan 2016 sehingga terdapat 117 unit analisis.

Pertimbangan dan kriteria yang ditentukan dalam penelitian iniuntuk pengambilan sampeladalahtersedianya datayang dibutuhkan untukdiolah dalam penelitian menggunakan kriteriaberikut:

1. Perusahaan perbankan yang terdaftar di BEI selama periode pengamatan yaitu selama tahun 2014-2016.

2. Perusahaan perbankan yang selalu menyajikan laporan keuangan dan laporan tahunan berturut-turut tahun 2014, 2015, dan 2016.

3. Perusahaan yang menyajikan data komisaris independen, dewan direksi, kepemilikan manajerial, risiko kredit, dan profitabilitas berturut-turut tahun 2014,2015, dan 2016.

\section{Definisi Operasional Variabel \\ Return on Asset (ROA)}

Rasio ini digunakan untuk mengukur kemampuan manajemen bank dalam memperoleh keuntungan (laba sebelum pajak) yang dihasilkan dari rata-rata total aset bank yang bersangkutan sehingga semakin besar ROA, semakin besar pula tingkat keuntungan yang dicapai bank. Surat Edaran Bank Indonesia, No.03/30/DNDP tanggal 14 Desember 2001, Return on Asset (ROA) merupakan rasio perbandingan antara laba sebelum pajak dengan rata-rata total aset. Sehingga rasio return on asset (ROA) dirumuskan sebagai berikut: 
$R O A=\frac{\text { Laba sebelum paak }}{\text { Rata }- \text { rata Total Aset }} \times 100 \%$

\section{Komisaris Independen (KIND)}

Komisaris Independen (KIND) merupakan anggota dewan komisaris yang bersifat independen sehingga keberadaannya dalam perusahaan bersifat netral dimana tidak memihak pemegang saham maupun manajemen. Dalam penelitian ini komisaris independen diukur dengan jumlah komisaris independen. Rumus yang digunakan untuk mengukur komisaris independen, sebagai berikut:

$K I N D=\frac{\text { jumlah komisaris independen }}{\text { jumlah dewan komisaris }} \times 100 \%$

\section{Dewan Direksi (DD)}

Dewan Direksi adalah Organ Perseroan yang berwenang dan bertanggung jawab penuh atas kepengurusan perseroan untuk kepentingan perseroan, sesuai dengan maksud dan tujuan perseroan serta mewakili perseroan baik di dalam maupun di luar pengadilan sesuai dengan ketentuan anggaran dasar. Jumlah anggota direksi disesuaikan dengan kepentingan perusahaan dengan tetap memperhatikan efektifitas dalam pengambilan keputusan secara efektif. Dewan direksi dapat diukur sebagai berikut:

$D D=$ jumlah dewan direksi

\section{Kepemilikan Manajerial (KM)}

Kepemilikan manajerial (KM) adalah tingkat kepemilikan saham pihak manajemen baik direksi maupun komisaris (kecuali komisaris independen) yang secara aktif ikut dalam pengambilan keputusan, diukur oleh proporsi saham yang dimiliki manajer pada akhir tahun yang dinyatakan dalam persentase (\%). Kepemilikan manjerial dapat dinyatakan dengan cara sebagai berikut:

$$
K M=\frac{\in \text { Saham yang dimiliki manajer }}{\in \text { Saham yang beredar }} \times 100 \%
$$

\section{Risiko Kredit (NPL)}

Non Performing Loan (NPL) merupakan perbandingan kredit bermasalah terhadap kredit yang disalurkan. Jadi rasio ini menggambarkan tentang risiko adanya kredit bermasalah yang dialami bank. Menurut Surat Edaran Bank Indonesia No.03/30/DNDP tanggal 14 Desember 2001, non performing loan (NPL) dapat diukur sebagai berikut:

$$
N P L=\frac{\text { Kredit bermasalah }}{\text { Kredit yang disalurkan }} \times 100
$$

\section{Prosedur Analisis Data}

Pengujian hipotesis penelitian ini dilakukan dengan menggunakan model analisis jalur (path analysis) yang dioperasikan melalui program Partial Least Square (PLS). Analisis jalur merupakan suatu teknik untuk menganalisis hubungan sebab akibat yang terjadi pada regresi linier berganda jika variabel independen mempengaruhi variabel dependen tidak hanya secara langsung tetapi juga secara tidak langsung (Ghozali, 2016:237). 


\section{Rekonstruksi Diagram Jalur ke Persamaan}

Dari model tersebut dibuat menjadi persamaan seperti di bawah ini:

$$
\begin{aligned}
& \operatorname{NPL}(\mathrm{Z})=\beta_{1} X_{1}+\beta_{2} X_{2}+\beta_{3} X_{3}+\hat{\varepsilon}_{1} \\
& \operatorname{ROA}(\mathrm{Y})=\beta_{1} X_{1}+\beta_{2} X_{2}+\beta_{3} X_{3}+\beta_{4} Z+\hat{\varepsilon}_{2}
\end{aligned}
$$

\section{HASIL PENELITIAN DAN PEMBAHASAN}

\section{Hasil Analisis Deskriptif}

\begin{tabular}{|c|c|c|c|c|c|c|c|c|c|}
\hline \multicolumn{3}{|c|}{ Delimiter: } & \multicolumn{2}{|c|}{ Comma } & \multicolumn{2}{|l|}{ Encoding: } & \multicolumn{2}{|c|}{ UTF-8 } & Re- - \\
\hline \multicolumn{3}{|c|}{ Value Quote Character: } & \multicolumn{2}{|c|}{ None } & \multicolumn{2}{|c|}{ Sample size: } & \multicolumn{2}{|c|}{117} & \\
\hline \multicolumn{3}{|c|}{ Number Format: } & \multicolumn{2}{|c|}{$\underline{\text { US (e.g. } 1,000.23)}$} & \multicolumn{2}{|l|}{ Indicators: } & \multicolumn{2}{|c|}{5} & \\
\hline \multicolumn{3}{|c|}{ Missing Value Marker: } & \multicolumn{2}{|c|}{ None } & \multicolumn{2}{|c|}{ Missing Values: } & & & \\
\hline \multirow[t]{2}{*}{ Indicators: } & \multicolumn{2}{|c|}{ Indicator Correlations } & Ran & & & & & & \\
\hline & No. & Missing & Mean & Median & Min & Max & Standard Deviation & Excess Kurtosis & Skewness \\
\hline KIND & 1 & 0 & 0.578 & 0.571 & 0.400 & 0.800 & 0.094 & -0.944 & 0.129 \\
\hline $\mathrm{DD}$ & 2 & 0 & 6.598 & 6.000 & 3.000 & 11.000 & 2.582 & -1.176 & 0.266 \\
\hline KM & 3 & 0 & 0.029 & 0.000 & 0.000 & 0.721 & 0.117 & 29.446 & 5.408 \\
\hline ROA & 4 & 0 & 0.010 & 0.013 & -0.112 & 0.047 & 0.024 & 9.020 & -2.541 \\
\hline NPL & 5 & 0 & 0.029 & 0.026 & 0.002 & 0.158 & 0.023 & 10.226 & 2.552 \\
\hline
\end{tabular}

Tabel 2. Statistik Deskriptif Variabel Penelitian

Sumber: Hasil Output PLS

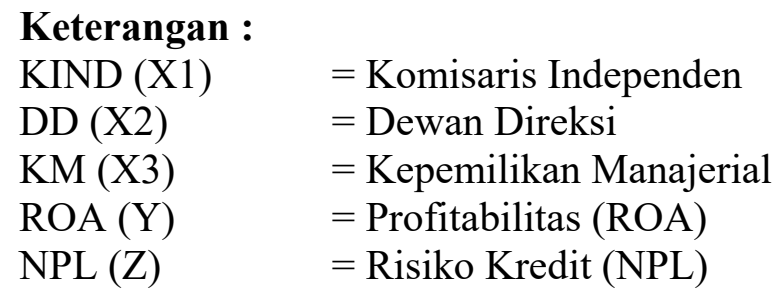

Berdasarkan tabel 2 dapat diketahui bahwa pengamatan di dalam penelitian ini sebanyak 117 sampel. Besarnya Komisaris Independen berkisar antara 0,400-0,800 dengan rata-rata sebesar 0,578 dan standar deviasi sebesar 0,094. Besarnya Dewan Direksi berkisar antara 3,000-11,000 dengan rata-rata sebesar 6,598 dan standar deviasi sebesar 2,582. Besarnya Kepemilikan Manajerial berkisar antara 0,000-0,721 dengan rata-rata sebesar 0,029 dan standar deviasi sebesar 0,117. Besarnya Profitabilitas (ROA) berkisar antara (-0,112)-0,047 dengan rata-rata sebesar 0,010 dan standar deviasi sebesar 0,024. Besarnya Risiko Kredit (NPL) berkisar antara 0,002-0,153 dengan ratarata sebesar 0,029 dan standar deviasi 0,023.

\section{Pengujian Kelayakan (Goddest of Fit) Inner Model}

\section{1) Uji Koefisien Determinasi $\left(\mathbf{R}^{2}\right)$}

Koefisien determinasi $\left(\mathrm{R}^{2}\right)$ digunakan untuk menunjukkan seberapa besar kemampuan konstruk eksogen menjelaskan variasi pada konstruk endogen yang dapat dilihat pada tabel 4.2 sebagai berikut: 
Tabel. 3 Hasil Uji Koefisien Determinasi $\left(\mathrm{R}^{2}\right)$

\section{R Square}

\begin{tabular}{|c|c|c|c|c|c|}
\hline \multirow[t]{2}{*}{ Matrix } & 㩰萃 & R Square & 掉竞 $\mathrm{R} \mathrm{Sq}$ & re Adjusted & \\
\hline & & & R Square & R Square $A c$ & justed \\
\hline NPL & & & 0.110 & & 0.086 \\
\hline ROA & & & 0.592 & & 0.577 \\
\hline
\end{tabular}

Sumber: Hasil Output PLS

Dari Pengujian Koefisien determinasi $\left(\mathrm{R}^{2}\right)$ dapat diketahui:

Profitabilitas (ROA) dapat dipengaruhi oleh Komisaris Independen, Komite Audit, dan Risiko Kredit (NPL) sebesar 59,2\% dan sisanya sebesar 40,8\% dipengaruhi oleh faktor lain yang tidak disertakan di dalam model.

Risiko Kredit (NPL) dapat dapat dipengaruhi oleh Komisaris Independen Dewan Direksi dan Kepemilikan Manajerial sebesar 11\% dan sisanya sebesar 89\% dipengaruhi oleh faktor lain yang tidak disertakan di dalam model.

\section{2) Uji Predictive Relevance $\left(\mathbf{Q}^{2}\right)$}

$\mathrm{Uji}$ predictive relevance $\left(\mathrm{Q}^{2}\right)$ digunakan untuk mengevaluasi prediktive relevance dari model yaitu berguna untuk validasi kemampuan prediksi model. Nilai $\mathrm{Q}^{2}>$ dari 0 (nol) menunjukkan bahwa model mempunyai predictive relevance, sedangkan nilai $\mathrm{Q}^{2} \leq$ dari 0 (nol) menunjukkan bahwa model kurang memiliki predictive relevance. Nilai $\mathrm{Q}^{2}$ didapatkan dengan memasukkan nilai $\mathrm{R}^{2}$ atau $\mathrm{R}$ Square ke dalam rumus $\mathrm{Q}^{2}$. Berikut adalah perhitungan untuk mendapatkan nilai $\mathrm{Q}^{2}$ :

$$
\begin{aligned}
\mathrm{Q}^{2} & =1-\left(1-\mathrm{R} 1^{2}\right)\left(1-\mathrm{R} 2^{2}\right) \ldots\left(1-\mathrm{Rp}^{2}\right) \\
& =1-(1-0,592)(1-0,110) \\
& =0,637
\end{aligned}
$$

Dari Pengujian Predictive Relevance $\left(\mathrm{Q}^{2)}\right.$ dapat diketahui bahwa model mempunyai predictive relevance atau kemampuan prediksi, karena $\mathrm{Q}^{2}>0$ (nol). Kedua hasil pengujian ini menunjukkan model secara keseluruhan fit dengan data atau mampu mencerminkan realitas dan fenomena yang ada dilapangan sehingga hasil penelitian ini dapat dinyatakan valid.

\section{Pengujian Hipotesis}

Pengujian hipotesis dilakukan untuk menjawab hipotesis yang telah dibuat oleh peneliti yaitu untuk mengetahui ada tidaknya pengaruh komisaris independen, dewan direksi, dan kepemilikan manajerial terhadap profitabilitas melalui risiko kredit. Dalam PLS pengujian secara statistik setiap hubungan yang dihipotesiskan dilakukan dengan menggunakan simulasi.

Tabel 4. Hasil Uji Hipotesis Pengaruh Langsung

\begin{tabular}{|l|l|l|l|l|}
\hline $\begin{array}{l}\text { ANALISIS } \\
\text { JALUR }\end{array}$ & $\begin{array}{l}\text { KOEFISIEN } \\
\text { REGRESI }\end{array}$ & PROBABILITAS & KETERANGAN & $\begin{array}{l}\text { SIMPULAN } \\
\text { HIPOTESIS }\end{array}$ \\
\hline $\begin{array}{l}\text { KIND } \\
\text { ROA }\end{array}$ & 0,073 & 0,417 & Tidak Signifikan & H1 ditolak \\
\hline $\begin{array}{l}\text { KIND } \\
\text { NPL }\end{array}$ & $-0,258$ & 0,001 & Signifikan & H2 diterima \\
\hline
\end{tabular}




\begin{tabular}{|l|l|l|l|l|}
\hline $\begin{array}{l}\text { DD } \\
\text { ROA }\end{array}$ & 0,295 & 0,000 & Signifikan & H3 diterima \\
\hline DD $\rightarrow$ NPL & $-0,187$ & 0,042 & Siginifikan & H4 diterima \\
\hline $\begin{array}{l}\text { KM } \\
\text { ROA }\end{array}$ & $-0,053$ & 0,324 & Tidak Signifikan & H5 ditolak \\
\hline KM NPL & $-0,187$ & 0,001 & Signifikan & H6 diterima \\
\hline $\begin{array}{l}\text { NPL } \\
\text { ROA }\end{array}$ & $-0,680$ & 0,000 & Signifikan & H7 diterima \\
\hline
\end{tabular}

Sumber : Diolah Penulis

Tabel 4 menunjukan hanya dua jalur yang tidak signifikan, yaitu Komisaris Independen terhadap Profitabilitas dan Kepemilikan Manajerial terhadap Profitabilitas, sedangkan jalur yang lain menunjukan adanya pengaruh.

Tabel 5 . Hasil Uji Hipotesis Pengaruh Tidak Langsung

\begin{tabular}{|l|l|l|l|l|}
\hline $\begin{array}{l}\text { ANALISIS } \\
\text { JALUR }\end{array}$ & $\begin{array}{l}\text { KOEFISIEN } \\
\text { REGRESI }\end{array}$ & PROBILITAS & KETERANGAN & $\begin{array}{l}\text { SIMPULAN } \\
\text { HIPOTESIS }\end{array}$ \\
\hline $\begin{array}{l}\text { KIND } \\
\text { ROA }\end{array}$ & 0,176 & 0,001 & Signifikan & H8 diterima \\
\hline $\mathrm{DD} \rightarrow$ ROA & 0,127 & 0,045 & Signifikan & H9 diterima \\
\hline KM $\rightarrow$ ROA & 0,127 & 0,001 & Signifikan & H10 diterima \\
\hline
\end{tabular}

Sumber : Diolah Penulis

Semua jalur pada Tabel 5 menunjukan adanya pengaruh, artinya ada pengaruh secara tidak langsung antara variabel independen terhadap variabel dependen melalui variabel intervening.

\section{Pengaruh Komisaris Independen terhadap Profitabilitas}

Hasil penelitian menunjukan komisaris independen tidak berpengaruh terhadap profitabilitas pada perbankan. Penelitian ini tidak sejalan dengan penelitian yang telah dilakukan oleh Sarafina dan Saifi (2017) sertaa Riniati (2015) yang menyimpulkan bahwa proporsi Komisaris Independen berpengaruh positif terhadap kinerja keuangan yang diukur dengan rasio ROA tetapi penelitian ini sejalan dengan penelitian yang dilakukan oleh Peruno (2015), Aprianingsih (2016) serta Putra dan Nuzula (2017) yang mengatakan bahwa besarnya proporsi komisaris independen tidak berpengaruh terhadap ROA dikarenakan peran dewan direksi yang dominan serta keberadaaan komisaris independen dalam perusahaan yang cenderung hanya bersifat formalitas untuk memenuhi aturan atau kebijakan pemerintah.

Dalam upayanya untuk melaksanakan tanggung jawab dengan baik, komisarsis independen harus secara proaktif mengupayakan agar mampu memberikan nasihat kepada dewan direksi untuk selalu bekerja secara baik dalam mengelola perusahaan demi kepentingan seluruh anggota perusahaan tetapi di dalam penelitian ini tingginya pihak indepedensi dari dewan komisaris dengan rata-rata sebesar 58,1\% yang telah memenuhi proporsi yang disyaratkan pada Peraturan Otoritas Jasa Keuangan Nomor 18 /POJK.03/2016 tidak berpengaruh terhadap probalitas perbankan, hal ini berarti tingginya proporsi dewan komisaris independen tidak menjamin terselenggaranya fungsi pengawasan secara efektif, maksimal dan objektif bilamana proporsi yang tinggi hanya dijadikan syarat untuk memenuhi regulasi dan peraturan yang ditetapkan di pemerintah tanpa disesuaikan dengan kondisi dan kebutuhan perbankan seperti terlihat pada Bank J Trust Indonesia Tbk. proporsi dewan komisaris independen memang telah memenuhi ketentuan yaitu sebesar 50\% tetapi pada jumlah dewan komisaris masih tidak 
sesuai dengan peraturan yang ada yaitu jumlah dewan komisaris minimal paling sedikit tiga orang sedangkan pada Bank J Trust Indonesia Tbk. hanya berjumlah dua orang dengan komisaris independen yang hanya berjumlah satu orang, sehingga tujuan dibentuknya komisaris independen memberikan sedikit kontribusi dalam fungsi pengawasan terhadap kinerja perusahaan sehingga pengawasan kepada dewan direksi menjadi kurang optimal. Selain itu, fungsi pokok komisaris independen yang hanya bertugas mengawasi dan memberi masukan atau saran atas pengelolaan perusahaan yang dilakukan dewan direksi tetapi tidak ikut campur dalam pengambilan keputusan operasional perusahaan, terlebih tinggi rendahnya pengawasan yang dilakukan komisaris independen lebih difokuskan unuk mengatasi kendala-kendala yang dihadapi dewan direksi dan menjaga agar tidak terjadi penyimpangan-penyimpangan yang dilakukan oleh dewan direksi yang berpotensi menimbulkan kerugian serta benturan kepentingan pada perusahaan.

\section{Pengaruh Dewan Direksi terhadap Profitabilitas}

Hasil penelitian ini menunjukkan bahwa dewan direksi berpengaruh positif terhadap profitabilitas, arah pengaruh yang positif terlihat pada nilai koefisien regresi sebesar 0,295 dimana artinya semakin tinggi jumlah dewan direksi, maka semakin tinggi ROA. Dewan direksi merupakan organ perseroan yang bertanggung jawab penuh secara kolektif atas pengurusan bank baik di dalam maupun di luar perusahaan, dewan direksi memiliki wewenang langsung dalam setiap kegiatan operasional perusahaan sehingga semakin banyak jumlah dewan direksi pada perusahaan berperan besar untuk mempengaruhi profitabilitas perusahaan. Profitabilitas perbankan yang baik menjadi salah satu komponen pengukur bagi dewan komisaris dan pemegang saham untuk menilai tingkat kinerja dewan direksi tersebut. Penelitian ini sejalan dengan penelitian yang dilakukan oleh Halini (2013) dan Aprianingsih (2014) yang mengatakan makin besarnya jumlah dewan direksi pada perusahaan sangat menentukan kebijakan yang akan diambil atau strategi perusahaan secara jangka pendek maupun jangka panjang. Penelitian ini tidak sesuai dengan penelitian Peruno (2015) dan Arumsari (2015).

\section{Pengaruh Kepemilikan Manajerial terhadap Profitabilitas}

Hasil penelitian ini menunjukkan bahwa kepemilikan manajerial tidak berpengaruh terhadap profitabilitas. Penelitian ini sejalan dengan penelitian yang dilakukan Widyati (2013), Aprianingsih (2016) dan Prahesti (2015) yang menyatakan tidak berpengaruhnya kepemilikan manajerial terhadap profitabilitas karena jumlah proporsi kepemilikan manajerial yang dimiliki oleh sampel perusahaan perbankan memiliki porsi yang kecil, hal ini menyebabkan manajemen kurang merasakan langsung manfaat dari pengambilan keputusan yang diambil.

Jumlah rata-rata sampel kepemilikan manajerial dalam penelitian ini sebesar 0,029 dimana masih tergolong rendah. Rendahnya jumlah kepemilikan manajerial berkaitan dengan biaya keagenan dimana semakin tinggi kepemilikan manajerial tentunya akan menambah kontrol dan pengawasan yang lebih ketat terhadap kinerja manajerial sehingga untuk menjaga biaya agensi yang tinggi serta untuk menerapkan prinsip independensi bagi pengelola perusahaan dimana berguna untuk menghindari benturan kepentingan sehingga sebagian besar perbankan memberikan batasan proporsi kepemilikan saham bagi manajer. Hasil penelitian ini tdak sejalan dengan penelitian yang dilakukan oleh Hasanah (2013) dan Indarti dan Extaliyus (2013. 


\section{Pengaruh Komisaris Independen terhadap Risiko Kredit}

Hasil penelitian ini menunjukkan bahwa komisaris independen berpengaruh negatif terhadap risiko kredit pada perbankan pengaruh yang negatif terlihat pada nilai koefisien regresi yang sebesar $(-0,258)$ dimana artinya semakin tinggi komisaris independen maka semakin rendah risiko kredit (NPL). Hasil penelitian ini sejalan dengan penelitian yang dilakukan oleh Setyorini (2015) dan Safitrie (2017) yang menyimpulkan bahwa GCG yang diproksikan dengan komisaris independen berpengaruh negatif terhadap risiko kredit karena pada Corporate Governance pengawasan yang dilakukan Komisaris Independen menjadi indikator penting dalam menerapkan prinsip kehati-hatian (prudential banking practices) sehingga risiko kredit yang dihadapi dapat diminimalisir.

Risiko kredit yang tidak bisa dihindari membuat keberadaan komisaris independen sangat dibutuhkan untuk mengawasi tugas dan tanggung jawab direksi dan manajer di dalam mengelola perusahaan yang tidak hanya berfokus meningkatkan keuntungan perusahaan tetapi memperhatikan setiap risiko yang melekat di dalamnya agar selalu mampu mengendalikan risiko dalam batas wajar yang ditentukan. Selain itu, berdasarkan Peraturan Otoritas Jasa Keuangan Nomor 18 /POJK.03/2016 perbankan diwajibkan membentuk komite pemantau risiko yang berada dibawah dewan komisaris dan harus terdiri dari anggota iomisaris Independen yang bertugas untuk melakukan evaluasi tentang kebijakan manajemen risiko, melakukan evaluasi tentang kesesuaian antara kebijakan manajemen risiko dengan pelaksanaan kebijakan tersebut, dan melakukan evaluasi pelaksanaan tugas komite manajemen risiko dan satuan kerja manajemen. Penelitian ini tidak sejalan dengan penelitian yang dilakukan Mirawati dan Halini (2014).

\section{Pengaruh Dewan Direksi terhadap Risiko Kredit}

Dari pengujian yang dilakukan diperoleh hasil bahwa dewan direksi berpengaruh negatif terhadap risiko kredit, arah pengaruh yang negatif terlihat pada nilai koefisien regresi yang sebesar $(-0,187)$ dimana artinya semakin tinggi jumlah dewan direksi, maka semakin rendah risiko kredit (NPL). Penelitian ini sesuai dengan penelitian Setyawati (2016) yang menyimpulkan implementasi GCG yang diproksikan dengan dewan direksi mampu berperan secara efektif mengatasi risiko perbankan khususnya risiko kredit. Semakin tinggi jumlah dewan direksi mengindikasikan semakin banyak tenaga profesional yang bertanggungjawab untuk mengatasi kendala-kendala dan risiko yang dihadapi perbankan. Dewan direksi selaku pengelola perbankan dituntut untuk selalu memperhatikan risiko-risiko yang melekat pada perusahaan baik jangka pendek maupun jangka panjang khusnya risiko kredit, dimana pengelolaan terhadap risiko tersebut akan berdampak besar kepada risiko-risiko lainnya. Adanya jumlah dewan direksi yang tinggi maka tentunya akan memberikan pengambilan keputusan yang lebih baik dan efisien sehingga pengelolaana adanya risiko kredit dapat diminimalisir, selain itu untuk memfokuskan pengelolaan terhadap risiko kredit, dewan direksi juga dibantu oleh komite manajemen risiko dan komite kredit yang bertanggung jawab langsung terhadap dewan direksi. Penwlitian ini tidak sesuai dengan penelitian yang dilakukan Halini (2012).

\section{Pengaruh Kepemilikan Manajerial terhadap Risiko}

Dari pengujian yang dilakukan diperoleh hasil bahwa kepemilikan manajerial berpengaruh negatif terhadap risiko kredit. Arah pengaruh yang negatif terlihat pada nilai koefisien regresi yang sebesar $(-0,187)$ dimana artinya semakin tinggi jumlah 
kepemilikan manajerial, maka semakin rendah risiko kredit (NPL). Penelitian ini sejalan dengan penelitian yang dilakukan oleh Paramitasari (2016) dan Setyorini (2015), dengan adanya kepemilikan yang dimiliki manajer akan menambah rasa memiliki atas perusahaan sehingga memberikan motivasi terhadap manajer untuk mengatasi kendala atau risiko khususnya risiko kredit yang merupakan risiko utama. Dengan adanya proporsi kepemilikan manajerial tentunya manajer akan lebih berhati-hati dalam setiap pengambilan keputusan khususnya mengenai kredit yang diberikan perusahaan, karena pemberian kredit yang berlebihan tanpa memperhatikan kualitas kreditnya akan berdampak pada risiko perusahaan jangka panjang yaitu kredit macet, selain itu dengan adanya proporsi kepemilikan manajerial akan mengurangi masalah keagenan antara pemegang saham dan manajer, karena selain sebagai pengelola perusahaan, manajer juga berperan sebagai investor yang tentunya akan selalu memperhatikan kesejahteraan pemilik saham dan menimimalkan kerugian yang ditimbulkan yang akan mempengaruhi kepercayaan investor. Hasil penelitian ini tidak sesuai dengan penelitian yang dilakukan Halini (2012).

\section{Pengaruh Risiko Kredit terhadap Profitabilitas}

Hasil penelitian ini menunjukkan bahwa risiko kredit berpengaruh negatif terhadap Profitabilitas perbankan. Arah pengaruh yang negatif terlihat pada nilai koefisien regresi yang sebesar $(-0,680)$ dimana semakin tinggi tingkat Risiko Kredit (NPL), maka semakin rendah ROA. Penelitian ini sejalan dengan penelitian yang dilakukan oleh Attar dkk (2014), Eng (2013) serta Joeswanto dan Malelak (2015) yang mengatakan NPL yang rendah menandakan pendapatan laba yang tinggi dikarenakan sedikitnya kredit bermasalah yang dialami oleh bank. Tingginya Risiko Kredit yang berpengaruh terhadap Profitabilitas perbankan berkaitan dengan kualitas kredit yang diberikan oleh sebuah bank. Dalam hal ini karena penyaluran kredit merupakan sumber utama pendapatan bank. Di sisi lain adanya kredit macet setidaknya akan dapat mengganggu perputaran modal kerja dari bank yang mempengaruhi laba perbankan. Maka manakala bank memiliki jumlah kredit macet yang tinggi, maka bank akan berusaha terlebih dahulu mengevaluasi kinerja mereka dengan sementara menghentikan penyaluran kreditnya hingga kredit macet berkurang. Hasil penelitian ini menunjukkan bahwa risiko kredit bank memiliki andil yang besar dalam pembentukan probilitas perbankan yang terlihat dari nilai koefisien sebesar 0,680 atau Risiko kredit mempengaruhi Profitabilitas sebesar 68\%. Dengan kata lain, ketika bank mampu menjaga risiko kreditnya dalam batas yang wajar atau bank mampu memanajemen risiko kreditnya dengan baik, pada akhirnya akan membawa bank pada kinerja yang lebih baik khususnya profitabilitas perbankan. Penelitian ini tidak sejalan dengan penelitian yang dilakukan Safitrie (2017) serta Mirawati dan Halini (2014) yang menyimpulkan Risiko Kredit tidak berpengaruh terhadapp Return on Assets (ROA) perbankan.

\section{Pengaruh Komisaris Independen terhadap Profitabilitas melalui Risiko Kredit}

Dari pengujian yang dilakukan diperoleh hasil bahwa Komisaris Independen berpengaruh positif terhadap profitabilitas melalui risiko kredit pada perbankan yang terdaftar di Bursa Efek Indonesia periode 2014-2016. atau pure mediation. Pada nilai koefisien regresi menunjukan angka yang positif sebesar 0,185 dimana artinya melalui NPL sebagai variabel intervening, semakin tinggi proporsi Komisaris Independen, maka semakin meningkat ROA sehingga hipotesis kedelapan diterima. Penelitian ini sejalan dengan penelitian yang dilakukan oleh Setyorini (2015) dan Setyawaty (2016) 
yang menyimpulkan adanya hubungan yang erat antara GCG dan manajemen risiko dimana semakin rendah risiko maka penerapan GCG semakin baik yang pada akhirnya mempengaruhi kinerja keuangan yang diukur dengan ROA.

Komisaris Independen dalam mengotrol dan mengawasi risiko-risiko dengan dibantu dengan komite pemantau risiko berperan penting agar dewan direksi dalam mengelola perbankan tidak hanya memperhatikan keuntungan jangka pendek tetapi juga memperhatikan keuntungan yang bersifat jangka panjang. Pengawasan yang difokuskan oleh komisaris independen melalui komite pemantau risiko memungkinkan pengawasan dilakukan lebih efektif, langsung ke titik permasalahan, dan efisien dalam pemanfaatan tenaga dan waktu serta perbankan lebih berhati-hati dalam pemberian dan penyaluran kredit, hasil pemeriksaan dan pengawasan yang dilakukan komisaris independen tersebut pada akhirnya akan digunakan kembali sebagai bahan untuk memutakhirkan profil risiko dan strategi oleh dewan direksi yasehingga akan berdampak pada peningkatan keuntungan perusahaan. Penelitian ini tidak sejalan dengan penelitian yang dilakukan Safitrie (2017).

\section{Pengaruh Dewan Direksi terhadap Profitabilitas melalui Risiko Kredit}

Dari pengujian yang dilakukan diperoleh hasil bahwa dewan direksi berpengaruh positif terhadap profitabilitas melalui risiko kredit pada perbankan atau parsial mediation. Pada nilai koefisien regresi menunjukan angka yang positif sebesar 0,127 dimana artinya melalui NPL sebagai variabel intervening, semakin tinggi jumlah dewan direksi, maka semakin meningkat ROA. Penelitian ini sejalan dengan penelitian yang dilakukan oleh Setyawati (2016) yang menyimpulkan dengan adanya penanganan terhadap risiko kredit memperkuat hubungan antara GCG yang diimplementasikan oleh dewan direksi.

Dewan direksi berpengaruh terhadap profitabilitas perbankan melalui risiko kredit dikarenakan penanganan atau manajemen terhadap risiko-risiko yang ada khususnya risiko kredit merupakan unsur terpenting dalam mewujudkan GCG dimana terjaganya risiko-risiko perbankan dalam batas minimum merupakan indikator penting untuk melihat keberhasilan penerapan GCG. Manajemen risiko yang baik berperan dalam memberikan jaminan yang wajar terhadap pencapaian tujuan perbankan sebagai lembaga yang mengandalkan kepercayaan masyarakat, memberikan perlindungan kepada para pemangku jabatan terhadap akibat buruk yang mungkin terjadi yang disebabkan oleh risiko khususnya risiko kredit dimana berbagai kebijakan dan tindakan untuk menjaga kualitas kredit perbankan akan berdampak pada peningkatan laba yang diperoleh. Setiap keputusan yang ditetapkan oleh dewan direksi tentunya sangat mempengaruhi kinerja perbankan yang tidak bisa dilihat dari segi pendapatan keuntungan yang tinggi tetapi juga perlu memperhatikan risiko-risiko dan tantantangan yang dihadapi perbankan dimana kedua hal tersebut tidak bisa dipisahkan, keputusan dewan direksi yang keliru yang hanya melihat keuntungan jangka pendek dari pemberian kredit yang besar tanpa memperhatikan kualitas kredit tentunya akan berdampak pada kerugian yang lebih besar pada jangka pendek akibat adanya kredit macet. oleh karena itu pentingnya jumlah dewan direksi yang memadai sehingga setiap keputusan dan kebijakan yang diambil akan memperhatikan segala aspek yang mempengaruhi keuntungan dan kesehatan perbankan terutama pengelolaan terhadap risiko perbankan. 


\title{
Pengaruh Kepemilikan Manajerial terhadap Profitabilitas melalui Risiko Kredit
}

Dari pengujian yang dilakukan diperoleh hasil bahwa kepemilikan manajerial berpengaruh positif terhadap profitabilitas melalui risiko kredit pada perbankan atau pure mediation. Pada nilai koefisien regresi menunjukan angka yang positif sebesar 0,127 dimana artinya melalui NPL sebagai variabel intervening, semakin tinggi kepemilikan manajerial, maka semakin meningkat ROA. Penelitian ini sejalan dengan penelitian yang dilakukan oleh Permatasary dan Novitasary (2014) serta Setyorini (2015) yang meyimpulkan dengan adanya proporsi kepemilikan manajerial aka menemukan bahwa risiko kredit mampu menjadi perantara yang menguatkan pengaruh kepemilikan manajerial terhadap ROA perbankan. Pengelolaan Risiko Kredit erat hubunganya dengan manajemen perbankan tersebut dimana setiap pengelolaannya menjadi tugas dan tanggung jawab manajer. Dengan adanya kepemilikan yang dimiliki manajer akan menambah rasa memiliki atas perusahaan sehingga memberikan motivasi terhadap manajer, sebagai pengelola perusahaan tentunya manajer memiliki informasi yang lebih lengkap sehingga sebagai pengelola manajer akan memprioritaskan keputusan dan kebijakan terhadap hal-hal yang lebih mendesak seperti penanganan terhadap risiko kredit yang akan mampu menciptakan kinerja perbankan stabil yang akan berdampak pada peningkatan profitabilitas perbankan sehingga akan menguntukan manajer sebagai investor.

\section{KESIMPULAN DAN SARAN}

\author{
Berdasarkan hasil analisis yang telah dilakukan, maka dapat diambil \\ kesimpulan sebagai berikut: \\ Komisaris independen dan kepemilikn manajerial tidak berpengaruh terhadap
} profitabilitas pada perbankan tetapi berpengaruh pada risiko kredit, dewan direksi berpengaruh terhadap profitabilitas perbankan dan risiko kredit, risiko kredit berpengaruh terhadap profitabilitas perbankan. Selain itu melalui risiko kredit komisaris independen, dewan direksi, dan kepemilikan manajerial berpengaruh terhadap profitabilitas atau dengan kata lain risiko kredit mampu berperan sebagai variabel intervening bagi Good Corporate Governance (GCG) sehingga penelitian ini membuktikan penerapan GCG yang diikuti dengan pengelolaan risiko yang baik akan mampu meningkatkan profitabilitas perbankan, hal ini dikarenakan penanganan atau manajemen terhadap risiko-risiko yang ada khususnya risiko kredit merupakan unsur terpenting dalam mewujudkan GCG dimana terjaganya risiko-risiko perbankan dalam batas minimum merupakan indikator penting untuk melihat keberhasilan penerapan GCG. Manajemen risiko yang baik berperan dalam memberikan jaminan yang wajar terhadap pencapaian tujuan perbankan sebagai lembaga yang mengandalkan kepercayaan masyarakat, memberikan perlindungan kepada para pemangku jabatan terhadap akibat buruk yang mungkin terjadi yang disebabkan oleh risiko khususnya risiko kredit dimana berbagai kebijakan dan tindakan untuk menjaga kualitas kredit perbankan akan berdampak pada peningkatan laba yang diperoleh.

\section{Saran}

Bagi perbankan, sebaiknya memberi perhatian yang cukup besar pada risiko kredit mengingat pengaruh yang cukup tinggi dari risiko kredit terhadap profitabilitas perbankan. Selain itu dalam penerapan mekanisme GCG, perbankan sebaiknya lebih memperhatikan proporsi komisaris independen agar didasarkan kebutuhan setiap perbankan sesuai dengan kompleksitas perbankan sehingga keberadaan komisaris 
independen lebih dirasakan manfaatnya karena dikhawatirksn jumlah yang terlalu banyak akan memakan biaya operasional yang akhirnya berimbas pada keuntungan perbankan sedangkan jumlah yang terlalu sedikit menyebabkan lemahnya fungsi pengawasan. Perbankan dirasa perlu menambah kepemilikan manajerial karena jumlah kepemilikan manajerial yang memadai memberikan kualitas GCG yang lebih baik khususnya penanganan terhadap risiko kredit tetapi pemberian hak kepemilikan saham oleh manajerial juga harus tetap dibatasi yaitu maksimal sebesar 5\% untuk menjaga prinsip independesi serta untuk menghindari terjadinya benturan kepentingan bagi pemilik saham minoritas.

Penelitian selanjutnya diharapakan untuk mencoba metode lain dalam melakukan pengukuran Good Corporate Governance (GCG), seperti dengan melakukan self assessment untuk menilai implementasi prinsip-prinsip Good Corporate Governance (GCG) dengan rentang waktu yang lebih lama dimana di dalam penelitian ini hanya menggunakan periode tiga tahun yaitu 2014-2016. Selain itu, peneliti selanjutnya juga diharapkan untuk mengembangkan variabel-variabel independen lain yang mungkin mempengaruhi risiko kredit karena dari hasil analisis koefisien determinasi, variabel independen hanya mampu menjelaskan variabel Risiko Kredit sebesar $11 \%$. Penelitian selanjutnya juga dapat mempertimbangkan jenis-jenis risiko lainnya dan tidak hanya berorientasi pada risiko kredit (NPL), seperti risiko pasar, risiko likuiditas, dan lain sebagainya karena risiko kredit bukanlah satu-satunya risiko yang mengancam perbankan.

\section{DAFTAR PUSTAKA}

Akmal, Huriyatul. 2008. Good Corporate Governance dan Manajemen Risiko di Bank Syari'ah. (Tesis Sarjana yang dipublikasikan, UIN Sunan Kalijaga, Yogyarkarta).

Ali, Masyudi. 2006. Manajemen Risiko Strategi Perbankan dan Dunia Usaha Menghadapi Tantangan Globalisasi Bisnis. Edisi Pertama. PT Rajagrafindo Persada. Jakarta.

Andriani, Ajeng dan Abdul Rozak. 2016. Analisis Pengaruh Penerapan Basel Capital Accord dan Good Corporate Governance terhadap Manajemen Risiko pada Perbankan Indonesia yang Terdaftar di Bursa Efek Indonesia. Conference of Management and Behavioral Studies Universitas Tarumanegara.

Anonymus.2004. Komite Nasional Kebijakan Corporate Governance Pedoman Good Corporate Governance Perbankan Jurnal Online Universitas Negeri Surabaya, Vol. 1, No. 1:234-249.Indonesia.

2006. Komite Nasional Kebijakan Corporate Governance. Pedoman Good Corporate Governance Indonesia.

Aprianingsih, Astri. 2016. Pengaruh Penerapan Good Corporate Governance, Struktur Kepemilikan, dan Ukuran Perusahaan terhadap Kinerja Keuangan Perbankan yang terdaftar di Bursa Efek Indonesia Periode 2011-2014. (Skripsi yang dipublikasikan, Universitas Negeri Yogyakarta).

Ariestya, P. Yutika dan Putu A. Ardiana. 2017. Implementasi Good Corporate Governance terhadap Kinerja Perusahaan Sektor Keuangan dengan Manaaemen Risiko Sebagai Variabel Intervening. Jurnal Akutansi Universitas Udayana, Vol.16, No. 2: 1461-1488.

Jumingan. 2006. Analisis Laporan Keuangan. Bumi Aksara. Jakarta. 
Arumsari, Violita Frida. 2014. Pengaruh Good Corporate Governance terhadap Kinerja Keuangan Bank Syariah. (Skripsi yang dipublikasikan, Universitas Muhammadiyah Surakarta).

Attar, Dini, Islahuddin dan Shabri M. 2014. Pengaruh Penerapan Manajemen Risiko terhadap Kinerja Keuangan Perbankan yang Terdaftar di Bursa Efek Indonesia. Jurnal Akuntansi, Pascasarjana Universitas Syiah Kuala, Vol. 3 No. 1: 10-20

Dendawijaya, Lukman. 2005. Manajemen Perbankan. Edisi Kedua. Ghalia Indonesia. Bogor.

Dewayanto, Totok. 2009. Pengaruh Mekanisme Good Corporate Governance terhadap Kinerja Perbankan Nasional". Jurnal Fokus Ekonomi, Vol. 5 No. 2:104-123.

Eng, Tan Sau. 2013. Pengaruh NIM, BOPO, LDR, NPL, dan CAR terhadap ROA Bank Internasional dan Bank Nasional Go Public Periode 2007-2011. Jurnal Dinamika Manajemen, Vol. 1 No. 3: 153-167.

Ferdyant, Ferli, Ratna Anggraini ZR, dan Erika Tadikah. 2014. Pengaruh Kualitas Penerapan Good Corporate Governance dan Risiko Pembiayaan terhadap Profitabilitas Perbankan Syariah, Vol. 1, No. 2: 134- 149.

Halini, Mirawati. 2012. Pengaruh Mekanisme Good Corporate Governance terhadap Kinerja Perusahaan Perbankan yang Terdaftar di Bursa Efek Indonesia pada Periode 2009- 2011. (Skripsi yang dipublikasikan, Univ. Esa Unggul Jakarta).

Hasanah Nur. 2013. Analisis Pengaruh Mekanisme Good Corporate Governance terhadap Kinerja Perbankan. (Skripsi yang dipublikasikan, Univ. Islam Negeri Syarif Hidayatullah)

Ibadil, Muhammad M. dan A. Mulyo Haryanto. 2014. Analisis Pengaruh Risiko, Tingkat Efisiensi, dan Good Corporate Governance terhadap Kinerja Keuangan Perbankan (Pendekatan Beberapa Komponen Metode Risk Based Bank Rating SEBI 13/24/DPNP/2011). Jurnal Studi Manajemen dan Organisasi, Vol. 11 No. 2: $126-142$.

Istighfarin, Diana dan Ni Gusti P. Wirawati. 2015. Pengaruh Good Corporate Governance terhadap Profitabilitas pada Badan Usaha Milik Negara (BUMN). Jurnal Akutansi Universitas Udayana, Vol. 13 No. 2:564-581.

.Joeswanto, D. Angela dan Mariana I. Malelak. 2015. Analisis Efek Mekanisme Good Corporate Governance terhadap Manajemen Risiko dalam Pembentukan Kinerja Perbankan. Jurnal FINESTA, Vol. 3 No. 1: 1-6.

Kuncoro, Mudrajad dan Suharjono.2011. Manajemen Perbankan Teori dan Aplikasi. Edisi Kedua. BPFE. Yogyakarta.

Mahardian, Pandu. 2008. Analisis Pengaruh Rasio CAR, BOPO, NPL, NIM dan LDR terhadap Kinerja Keuangan Perbankan. (Tesis Sarjana yang dipublikasikan, Universitas Diponegoro).

MG. Kentris Indarti dan Lusi Extaliyus. 2013. "Pengaruh Corporate Governance Preception Index (CGPI), Struktur Kepemilikan, dan Ukuran Perusahaan terhadap Kinerja Keuangan”. Jurnal Bisnis dan Ekonomi. Vol. 20, No. 2. Mulyadi. 2001. Akuntansi Manajemen: Konsep, Manfaat, dan Rekayasa. STIE YKPN. Yogyakarta. 
Paramitasari, Selly Dana. 2016. Analisis Pengaruh Corporate Governance terhadap Risiko Kredit dan Kinerja Keuangan Perbankan Umum di Indonesi (Studi pada Perbankan Umum yang terdaftar di BEI Tahun 2010-2014). (Skripsi yang dipublikasikan, Universitas Sebelas Maret Surakarta).

Permatasari, Ika dan Retno Novitasary. 2014. Pengaruh Implementasi Good Corporate Governance: Manajemen Risiko sebagai Variabel Intervening. Jurnal Ekonomi Kuantitatif Terapan, Vol 7, No. 1:52-59.

Peruno, Dwipayana Danil, 2015. Pengaruh Mekanisme Good Corporate Governance terhadap Kinerja Perusahaan Perbankan yang terdaftar di Bursa Efek Indonesia tahun 2009-2011. (Skripsi yang dipublikasikan, Universitas Negeri Yogyakarta).

Prahesti, D. Shinta dan Nyoman Abundati. 2015. Pengaruh Risiko Kredit, Struktur Kepemilikan dan Dewan Komisaris Independen Independen tehadap Kinerja Keuangan pada Industri Perbankan di Bursa Efek Indonesia. Jurnal Manajemen Universitas Udayana, Vol. 4, No. 1:457-481.

Puspitasari, H. Dwi. 2014. Pengaruh Penerapan Tata Kelola Perusahaan terhadap Risiko Kredit Melalui Rasio Kecukupan Modal pada Bank Umum. Jurnal Ilmu Manajemen, Vol. 2 No. 4: 1691-1702.

Riniati, Kuslinah. 2015. Pengaruh Komisaris Independen dan Komite Audit terhadap Kinerja Perusahaan (Perusahaan yang Terdaftar di BEI 2011-2013). (Skripsi yang dipublikasikan, Universitas Negeri Yogyakarta).

Safitrie, Dian (2017). Pengaruh Dewan Komisaris Independen terhadap Profitabilitas Bank Syariah dengan Non Performing Financing (NPF) sebagai Variabel Intervening. (Skripsi yang dipublikasikan, Institut Agama Islam Negeri Salatiga)

Sarafina, salsabila dan Muhammad Saifi. 2017. Pengaruh Good Corporate Governance terhadap Kinerja Keuangan dan Nilai Perusahaan (Studi pada Badan Usaha Milik Negara (BUMN) yang Terdaftar di Bursa Efek Indonesia Periode 2012 - 2015. Jurnal Administrasi dan Bisnis, Vol. 50. No. 3: 108-117.

Sari, Irmala. 2010. Pengaruh Mekanisme Good Corporate Governance terhadap Kinerja Perbankan Nasional. (Skripsi yang Dipublikasikan, Univ. Diponegoro).

Setyawati, Agus. 2016. Pengaruh Mekanisme Good Corporate Governance terhadap Kinerja Perbankan dengan Manajemen Risiko Sebagai Variabel Interverning. Jurnal Ekonomi dan Manajemen, Vol. 13, No.1: 13-24.

Setyorini, Hesti Octavia. 2015. Peran Manajemen Risiko Untuk Memediasi Pengaruh Mekanisme Good Corporate Governance Terhadap Kinerja Keuangan Pada Perusahaan Yang Terdaftar di Perbankan Bursa Efek Indonesia Tahun 20102013. (Skripsi yang Dipublikasikan, Universitas Negeri Semarang).

, Indra. 2011. Implementasi Good Corporate Governance pada Kinerja Bank Syariah. Jurnal Akutansi Multiparadigma, Vol. 7 No. 2:307-321.

Sugiyono. 2011. Metode Penelitian Kuantitatif, Kualitatif, Dan $R \&$ D. Alfabeta. Bandung.

Sukamulja, Sukmawati. 2004. Good Corporate Governance di Sektor Keuangan: Dampak GCG terhadap kinerja Perusahaan (Kasus di Bursa Efek Jakarta). Jurnal BENEFIT, Vol. 8, No. 1: 1-25 
Sulistyowati. 2017. Pengaruh Good Corporate Governance terhadap Kinerja Keuangan Pada Perusahaan Perbankan. Jurnal Ilmu dan Riset akutansi, Vol. 6 No. 1: 121137.

Syamsudin, Lukman. 2004. Manajemen Keuangan Perusahaan; Konsep Aplikasi dalam Perencanaan, Pengawasan, dan Pengambilan Keputusan. Edisi Baru. Raja Grafindo. Jakarta.

Tertius, Melia A. dan Yulius J.C. 2015. Pengaruh Good Corporate Governance terhadap Kinerja Perusahaan Sektor Keuangan. Jurnal Business Acounting Rivew, Vol. 3 No. 1:223-232.

Widyati, Maria F. 2013. "Pengaruh Dewan Direksi, Komisaris Independen, Komite Audit, Kepemilikan Manajerial, dan Kepemilikan Institusional terhadap Kinerja Keuangan".

Anonymus.2004. Komite Nasional Kebijakan Corporate Governance Pedoman Good Corporate Governance Perbankan Jurnal Online Universitas Negeri Surabaya, Vol. 1, No. 1:234-249.Indonesia.

. 2006. Komite Nasional Kebijakan Corporate Governance. Pedoman Good Corporate Governance Indonesia.

Bank Indonesia. 1998. Undang-Undang Republik Indonesia Nomor 10 tahun 1998 tentang Perbankan

. 2011. Peraturan Bank Indonesia No 13/1/PBI/2011 tentang Penilaian Tingkat Kesehatan Bank Umum.

. 2013. Kodifikasi Peraturan Bank Indonesia Manajemen Good Corporate Governance.

Otoritas Jasa Keuangan. 2015. Peraturan Otoritas Jasa Keuangan No.55/POJK.04/2015 tentang Pembentukan dan Pedoman Pelaksanaan Kerja Komite Audit.

. 2015. Surat Edaran Otoritas Jasa Keuangan Nomor 14/SEOJK.03/2015 tentang Penerapan Manajemen Risiko Terintegrasi Bagi Konglomerasi Keuangan . 2016. Peraturan Otoritas Jasa Keuangan Nomor 17/POJK.03/2014 tentang Penerapan Manajemen Risiko Terintegrasi Bagi Konglomerasi Keuangan.

. 2016. Peraturan Otoritas Jasa Keuangan Nomor 18/POJK.03/2016 tentang Penerapan Manajemen Risiko Bagi Bank Umum

. 2016. Peraturan Otoritas Jasa Keuangan No. 55/POJK.03/2016 tentang Penerapan Tata Kelola Bagi Bank Umum.

. 2016. Surat Edaran Otoritas Jasa Keuangan Nomor 34/SEOJK.03/2016 tentang Penerapan Manajemen Risiko Bagi Bank Umum.

Qorib, Fathan. (2013, 24 Juni) BI Sebut Empat Bank Tak Terapkan GCG: http://www.hukumonline.com, diakses tanggal 4 Februari tahun 2018.

www.idx.co.id

www.ojk.go.id.

www.sahamok.com 